\title{
Mediating Service Recovery Satisfaction in the Relationship between Internet Service Recovery and Customer Loyalty
}

\author{
Mauro Sciarelli ${ }^{1}$, Abdelhakim A. Nagm ${ }^{2}$, Mona I. Dakrory ${ }^{2}$, Mario Tani ${ }^{1} \&$ Mohamed A. Khashan ${ }^{2}$ \\ ${ }^{1}$ Departiment of Economics, Management and Institutions - University of Naples Federico II, Naples, Italy \\ ${ }^{2}$ Department of Business Administration, Faculty of Commerce, Mansoura University, Mansoura, Egypt \\ Correspondence: Mohamed A. Khashan, Department of Business Administration, Mansoura University, 35516 , \\ Mansoura, Egypt. Tel: 020-100-971-9611.E-mail: m_khashan@mans.edu.eg
}

Received: June 26, 2017

doi:10.5539/ijbm.v12n10p24
Accepted: September 5, 2017 Online Published: September 17, 2017

URL: https://doi.org/10.5539/ijbm.v12n10p24

\begin{abstract}
This current study purposes to identify the relationships between service recovery strategies, service recovery satisfaction, and both dimensions of customer loyalty in regard to Internet providers using the partial least squares (PLS-SEM) approach on a sample of 430 internet customers in Egypt.

This study contributes insights into how seven service recovery strategies affected customer loyalty with its both attitudinal and behavioral dimensions directly and indirectly via service recovery satisfaction. These insights are helpful for service managers faced with service failure and academicians interested in how service providers respond to service failures and customer dissatisfaction in the $\mathrm{B} 2 \mathrm{C}$ context.

The results of this study show that some SR strategies positively influence both service recovery satisfaction and customer loyalty toward internet providers. Furthermore, service recovery satisfaction positively influencing the customer loyalty. In addition, SRS plays a mediating role in the relationship between SR strategies and customer loyalty. The results highlight that internet service providers should implement SR strategies quickly and with an empathetic manner to satisfy customers and to encourage customer's loyalty. Finally, some implications and further research directions were presented.
\end{abstract}

Keywords: service recovery, service recovery satisfaction, attitudinal loyalty, behavioral loyalty, internet service provider

\section{Introduction}

Service marketing literature confirms that the firm's profitability is mostly determined by the loyalty of their customers (Komunda \& Osarenkhoe, 2012), where Reichheld and Sasser (1990) illustrate that the improvement in customer retention by $5 \%$ can lead to an increase in profits ranging from $25 \%$ to $85 \%$. Therefore, the leading companies in business today have become aware of the importance of customer loyalty as it considered one of the best intangible assets for any service firm and it represents a necessity to remain in the competitive market (Cossío-Silva, Revilla-Camacho, Vega-Vázquez, \& Palacios-Florencio, 2016; Yang \& Chao, 2017 ). As well as, it is considered a strategic element for a long-term viability in the B2C context (Chen \& Wang, 2016; Hsiao \& Chen, 2016) and it plays an essential role in achieving more profits and firms' success (Kim, 2007) especially in the e-commerce context (Hsiao and Tang, 2016). In addition to this, a loyal customer represents a great marketing force for companies through their positive word of mouth (Johnston and Michel, 2008; Jung and Seock, 2017). It follows that one of the main goals of modern companies is to attract and maintain a loyal customer (Eakuru \& Mat, 2008; Chen \& Wang, 2016; Kamran-Disfani, Mantrala, Izquierdo-Yusta, \& Martínez-Ruiz, 2017).

Zemke and Bell (1990) pointed that the actual test of service firm's commitment toward service quality can be found in its response to the service failure. So that, service recovery has considered a strategic element for service firms in the competitive marketplace (Yaya, Marimon, \& Casadesus, 2013), and it has been identified as a key issue in the literature of both service marketing and service quality (Ashill, Carruthers, \& Krisjanous, 2005; Michel, Bowen, and Johnston, 2009; Cheung \& To, 2016), especially that the service failure is not completely avoidable due to the intangible nature of service (Jung \& Seock, 2017). In addition to this, it represents a key tool to companies wanting to maintain satisfied and loyal customers (Sousa \& Voss, 2009). Service recovery also 
contributes to the positive assessment of the service provider by its customers in the $\mathrm{B} 2 \mathrm{C}$ context, which can build customer relationships (Michel et al., 2009; Park \& Park, 2016) and lead to improving their satisfaction, trust and commitment aspects (Singh \& Sirdeshmukh, 2000; Sirdeshmukh, Singh, \& Sabol, 2002; Morgan \& Hunt, 1994; Michel et al., 2009).

Andersson, Graselius, and Nilsson (2005) believed that service recovery satisfaction can be considered a primary determinant of long-term customer/service provider relationships, as well as it considered one of the cornerstones of marketing (Cambra-Fierro, Pérez, \& Grott, 2017), and is essential element to the survival of any organization (Cheung \& To, 2016). The higher the level of customer satisfaction perceived, the greater the customer retention rate and financial returns for the service provider. When the customer suffers, the business firm may lose more than just the value of the next transaction, it may also lose a long-term flow of profits that come from this particular customer and from anyone else who advised against dealing with that firm in the future by those dissatisfied customers (Wirtz \& Lovelock, 2011, p. 354; De Matos, Henrique, \& Alberto Vargas Rossi, 2007). Therefore, service companies have to pay attention to service recovery satisfaction because of its role in customer retention.

The ICT sector is considered one of the main pillars to build a knowledge economy, it is also considered as one of the key sectors contributing to support economic and social development (economic quarterly report, General Authority for Investment and Free Zones, Egypt, July / September 2012 / 2013). The Egyptian ICT sector contributes by $10.2 \%$ in the Egyptian economic growth. In addition to, the growing use of the Internet service by the Egyptian customer, where the ADSL customers were growing by $22.5 \%$ in January-March 2016 compared to the same period in 2015 (ICT Indicators, March 2016). Therefore, we concentrate in that sector in the current study because of our believing in its vital role in the Egyptian economy growth.

This study mainly seeks to examine how service recovery strategies affecting the loyalty of Egyptian internet customers directly and through a mediating the role of SRS. This paper builds on the SR strategies proposed by Liao (2007) (making apology, problem-solving, providing explanation, empathy, speed of recovery) and we have considered two more strategies from other studies (compensation, follow-up) because they seem appropriate to the nature of this study based on the related literature in the eastern communities and our pilot study (see Mostafa, Lages, Shabbir, \& Thwaites, 2015; Sciarelli, Nagm, Dakrory, Tani, \& Khashan, 2017). Komunda and Osarenkhoe (2012) found that service recovery as a whole influenced word of mouth (WOM) communications and repurchase intentions. In addition, Yaya et al. (2013) stated that service recovery (responsiveness, contact) influenced customer loyalty as a whole, however this research will examine the relationship between each seven SR strategies (i.e. apologizing, p. solving, providing explanation, speed of recovery, empathy, compensation, follow-up) and customer loyalty dimensions (i.e. attitudinal and behavioral loyalty) in the context of internet services mostly ADSL services.

This study also aims to participate in the debate of which service recovery strategies influence service recovery satisfaction (SRS). Some studies confirmed that apology and compensation have a positive impact on SRS while there was no significant effect of problem solving on SRS (Kim, 2007). Ikponmwen (2011) found that apologizing, providing explanations, and giving a follow-up have a positive significant effect on SRS. Moreover, Wirtz and Mattila (2004) found a significant effect on SRS by compensation, the speed of recovery, and apologizing. With regarding Egyptian context, Mostafa, Lages, and Sääksjärvi (2014) found that problem solving, the speed of response, effort, facilitation, and apology are positively affecting SRS but compensation, explanation, follow up and courtesy not have an impact on SRS in mobile phone service. We want to identify the main strategies that affect SRS especially in the internet services context in the eastern communities.

This paper is organized into five sections as follows. The first one includes the theoretical background and hypotheses development. The second related to our study methodology as well as the third section clarifies our data analysis and results. The fourth section contains the discussion of the main results. Finally, the last section includes the conclusion, implications, as well as study limitations and directions for further research.

\section{Theoretical Background and Hypotheses}

\subsection{Service Recovery (SR)}

According to Zemke and Schaaf, 1989, the idea of "recovery" was originally used in a service environment from British Airway's (BA) "putting the customer first" campaign (Lin, 2006), which was the initial program established for front-line staff to learn how to work together more effectively and to focus their attention on the customer (Jarvis, 2014). So that, SR does not just refer to "return to a normal state" but to a state of enhanced customer's perception (Pycraft, 2000, p. 721). 
Gronroos (1988) suggested that a service recovery represents all corrective action that a service provider takes in response to a service failure or poor quality service. Zemke and Bell (1990) defined SR as: "a thought-out process for returning aggravated customers to a state of satisfaction with the company after a service has failed to exceeds the customer's expectations". Boshoff, (1999) confirmed Zemke and Bell (1990) description but added that an effective SR process must be proactive in nature opposed to reactive. McCollough, Berry, and Yadav (2000) pointed that the recovery efforts were all actions performed by the service firm to return a customer to a satisfied status with that firm, which even could either destroy or enhance their future behavioral intention toward that particular service firm. The concept of SR also comprises all strategies and tactics that the provider carry out as a response to a service failure to return the customer satisfaction level at its previous level and of keeping the customer loyal or at least retain him/her as a customer (Andreassen, 2000; Miller, Craighead, and Karwan, 2000; Andersson et al., 2005; Petzer, Steyn, and Mostert, 2009).

A company can exploit many different strategies to SR. In Table 1, we report the strategies each previous study of SR has taken into account.

\section{A. Making an apology}

Zemke and Bell (1990) suggested that apologizing is considered the first step in restoring equity from a service providers' perspective through acknowledging at the very least that the customer has been inconvenienced, even if the service firm does not responsible the wrongdoing. So that, apologies refer to acknowledging the service firm's responsibility for negative events and it includes some expression of remorse and regret (Liao, 2007). The apology also refers to an employee's apology rather than a company apology, in addition to acknowledges that a failure has occurred (Ennew and Schoefer, 2003). In addition, it represents a psychological compensation about service failure (Park and Park, 2016). Battaglia, Borchardt, AfonsoSellitto, and MedeirosPereira (2012) suggested that this dimension depending on the failure severity, in addition to the provision of a refund or compensation.

Table 1. Main strategies of SR

\begin{tabular}{|c|c|c|c|c|c|c|c|c|}
\hline \multirow[b]{2}{*}{ Author(s) } & \multirow[b]{2}{*}{ Year } & \multicolumn{7}{|l|}{ SR strategies } \\
\hline & & $\begin{array}{l}\text { 1. Making } \\
\text { an apology }\end{array}$ & $\begin{array}{l}2 . \\
\text { Problem } \\
\text { solving } \\
\end{array}$ & $\begin{array}{l}\text { 3. Providing } \\
\text { an } \\
\text { explanation }\end{array}$ & $\begin{array}{l}\text { 4. Speed } \\
\text { of } \\
\text { recovery }\end{array}$ & $\begin{array}{l}5 . \\
\text { Empathy }\end{array}$ & $\begin{array}{l}6 . \\
\text { Compensation }\end{array}$ & $\begin{array}{l}7 . \\
\text { Follow-up }\end{array}$ \\
\hline Bell \& Zemke & 1987 & $\sqrt{ }$ & & & $\sqrt{ }$ & $\sqrt{ }$ & $\sqrt{ }$ & $\sqrt{ }$ \\
\hline Zemke \& Bell & 1990 & $\sqrt{ }$ & $\sqrt{ }$ & $\sqrt{ }$ & & & $\sqrt{ }$ & \\
\hline Boshoff & 1999 & $\sqrt{ }$ & & $\sqrt{ }$ & $\sqrt{ }$ & $\sqrt{ }$ & $\sqrt{ }$ & $\sqrt{ }$ \\
\hline Levesque \& McDogugall & 2000 & $\sqrt{ }$ & $\sqrt{ }$ & & & & $\sqrt{ }$ & \\
\hline Ennew \& Schoefer & 2003 & $\sqrt{ }$ & & & $\sqrt{ }$ & $\sqrt{ }$ & $\sqrt{ }$ & $\sqrt{ }$ \\
\hline Wirtz \& Mattila & 2004 & $\sqrt{ }$ & & & $\sqrt{ }$ & & $\sqrt{ }$ & \\
\hline Lewis \& McCann & 2004 & $\sqrt{ }$ & $\sqrt{ }$ & $\sqrt{ }$ & & $\sqrt{ }$ & $\sqrt{ }$ & \\
\hline Boshoff et al. & 2005 & $\sqrt{ }$ & & $\sqrt{ }$ & & $\sqrt{ }$ & $\sqrt{ }$ & $\sqrt{ }$ \\
\hline Duffy et al. & 2006 & $\sqrt{ }$ & $\sqrt{ }$ & & & & $\sqrt{ }$ & \\
\hline Lin & 2006 & $\sqrt{ }$ & $\sqrt{ }$ & & & & $\sqrt{ }$ & \\
\hline Kim & 2007 & $\sqrt{ }$ & & $\sqrt{ }$ & & $\sqrt{ }$ & $\sqrt{ }$ & \\
\hline Liao & 2007 & $\sqrt{ }$ & $\sqrt{ }$ & $\sqrt{ }$ & $\sqrt{ }$ & $\sqrt{ }$ & & \\
\hline Johnston \& Michel & 2008 & $\sqrt{ }$ & $\sqrt{ }$ & & & $\sqrt{ }$ & $\sqrt{ }$ & \\
\hline Battaglia et al. & 2012 & $\sqrt{ }$ & $\sqrt{ }$ & & $\sqrt{ }$ & $\sqrt{ }$ & & \\
\hline Chou & 2015 & $\sqrt{ }$ & & & & & $\sqrt{ }$ & \\
\hline Mostafa et al. & 2015 & $\sqrt{ }$ & $\sqrt{ }$ & $\sqrt{ }$ & $\sqrt{ }$ & $\sqrt{ }$ & $\sqrt{ }$ & $\sqrt{ }$ \\
\hline Park and Park & 2016 & $\sqrt{ }$ & & $\sqrt{ }$ & $\sqrt{ }$ & $\sqrt{ }$ & $\sqrt{ }$ & \\
\hline Jung \& Seock & 2017 & $\sqrt{ }$ & & & & & $\sqrt{ }$ & \\
\hline Sciarelli et al. & 2017 & $\sqrt{ }$ & $\sqrt{ }$ & $\sqrt{ }$ & $\sqrt{ }$ & $\sqrt{ }$ & $\sqrt{ }$ & $\sqrt{ }$ \\
\hline
\end{tabular}

\section{B. Problem solving}

Problem solving represents the main effective SR strategy, as it can bring the customer back to the expected level service. Accordingly, service firms should fix the customer's problem quickly because the gain in fulfilling this basic promise may equal the loss from the failure (Levesque and McDogugall, 2000). Battaglia et al. (2012) also 
described it as an ability to recognize the reasons for failure, to plan and, then, to implement corrective actions.

\section{Providing an explanation}

Conlon and Murray (1996), Boshoff (1999) and Liao (2007) argue that providing the explanations to customers refers to explaining the reasons for service failure in a clear and specific way. Moreover, the enterprise should let the customer know the reasons behind the service failure (Ikponmwen, 2011: p. 39) and explain to them how service organizations are aware of customer problems (Park and Park, 2016). Although some customers may view the explanation as an important portion of valuable and desirable outcomes, it may bring negative outcomes from those customers believing that it is just an attempt from the service provider to justify its service failures while trying not to take the blame (Liao, 2007).

\section{Speed of recovery}

This strategy denotes the service provider's quick response to a service failure or to a customer complaint (Liao, 2007). Although the quick response is seen as a valuable outcome from a customer perspective, a late one will indicate to customers the provider's guilt and its attempt to postpone the needed actions (Conlon and Murray, 1996). In addition, time delays increase the customer's dissatisfaction and negatively influences on their perceptions of service quality (Boshoff, 1999). It also refers to the speed of service provider actions coupled with a brave attempt to put things right and to correct the situation (Ennew and Schoefer, 2003). Battaglia et al. (2012) suggested that it is the ability to contain the problems of customers quickly. Moreover, it improves the opportunity of keeping the relationship with dissatisfied customers after service failure (Park and Park, 2016).

\section{E. Empathy}

Empathy has been viewed as caring, interest, and individualized attention that the service firm provides to its customers (Zeithaml, Parasuraman, and Berry, 1990, p. 26). It also refers to dealing with customers in a manner that shows that the service firm interested in solving the customer problem and decreasing his/her inconvenience (Boshoff, 1999). So that, the respectful interaction between service firm and its dissatisfied customers has gained a high priority in the service recovery context (Park and Park, 2016).

Liao (2007) mentioned that this service recovery strategy is based upon the behavior of the service provider employee. It should prove politeness, appreciation, friendliness, and patience when interacting with the customers. Empathy also refers to a deep expression of feeling for the customer's dilemma (Ennew and Schoefer, 2003). It indicates the ability to understanding the problem from the customer's perspective and highlight the provider's attention and the importance given to it (Battaglia et al., 2012).

\section{F. Compensation}

Compensation strategy is about giving the customer some value-added benefit to balance the negative effects caused by the service failures (Boshoff, 1999). It has been defined as the payment for the service failure through offering future services free or giving discounts to customers affected (Ennew and Schoefer, 2003; Park and Park, 2016). Consequently, Johnston and Michel (2008) pointed that the real effect of providing a compensation depends on the severity of the problem the customer has endured.

\section{G. Follow-up}

The follow-up, or feedback, denotes to making the customers always aware with all information related to their problems as well as what the service firm doing to resolve it (Boshoff, Hoogendoorn, and vander Kraan, 2005). It is an after-recovery activity to check if the customer is happy with the provider efforts toward service failure or not (Ennew and Schoefer, 2003). So that, follow-up is useful in managing customer's satisfaction as it let the service provider create a service provider to gather data on the way it has really solved the customer's problem (Johnston and Mehra, 2002).

\subsection{Service Recovery Satisfaction (SRS)}

Effective SRS has become an important topic of interest and study as it plays a crucial role especially in the service industry (Edvardsson, Johnson, Gustafsson, \& Strandvik, 2000). Thus, one of the primary goals of these firms should be trying to satisfy their customers (Blodgett, Granbois, \& Walters, 1993; Lin, 2006), as not being able to satisfy customers can be one of its worst liabilities (Edvardsson et al., 2000). Moreover, Roos (1999) holds that when the service provider handled improperly a case of service failure, it can lead to a customer's switching behavior.

Oliver (1997, p. 13) defined satisfaction as the customer's evaluation that a product or service itself or its feature has been able to provide a pleasant level of consumption. It is not a single level as a customer's request can be under- or over- fulfilled by the service provider. Oliver (1981, p. 27) define it as "summary psychological state 
resulting when the emotion surrounding disconfirmed expectations is coupled with the consumer's prior feelings about the consumption experience".

In service recovery context, Choi and La (2013); Park and Park, (2016) suggest that SRS, which also refers to satisfaction with complaint handling (Tax, Brown, \& Chandrashekaran, 1998), is the customer's evaluation of how well the provider deals with a failure in providing service. It is a very critical factor as it helps to maintain healthy relationships with customers (Fornell \& Wernerfelt, 1987). It also refers to the extent to which the customers have favorable emotions to provider's recovery efforts (Chang, 2004). It refers to customer's feelings and attitude after the consumption of services or service recovery (Cheung \& To, 2016).

Therefore, Yuksel and Rimmington, (1998), suggest that the service provider, which evaluates the level of customer satisfaction and apply that knowledge to improve the delivery of services, usually achieves a significant competitive advantage. Therefore, the customer satisfaction assessment is essential to increase customer retention and to encourage positive WOM communication.

\subsection{Customer Loyalty (CL)}

Customer loyalty construct has always attracted the attention of both academics and practitioners (Kamran-Disfani et al., 2017), as a consequence, most service providers have dramatically changed their approach to it. Although customer loyalty research mainly focused on purchase behavior, the research efforts recently have adopted a broader approach focusing on customer's expectations, perceptions, and attitudes (Mason, Tideswell, \& Roberts, 2006).

In 1969, Day revealed that the customer loyalty is a specific state in which the repurchase behavior is coupled with a psychological and emotional attachment of customers toward the service provider. Jacoby and Chestnut (1978) mentioned that understanding loyalty requires examining the belief, attitude, and cognitive structure of the customer's orientation toward the service provider (Dai, 2002). It has been described as the strength of the link between a customer's relative attitude and a repeated patronage (Dick \& Basu, 1994). Customer loyalty has been seen as deeply held commitment to rebuy, or re-patronize, a desired product or service regularly in the future, thereby causing repetitive same-brand or same-brand set purchasing behavior, regardless of situational influences and marketing efforts that potentially cause the switching behaviors (Oliver, 1997, p. 392).

With regard to CL dimensions, Day, (1969) was considered developed a composite perspective of customer loyalty, he saw that the customer should be considered as a truly loyal one if he couples a positive attitude toward the brand in addition to the repeat purchase behavior. In other words, loyalty means repeat purchase based on a cognitive, affective and evaluative basis.

Jacoby and Chestnut (1978) categorized three types of loyalty: behavioral, attitudinal, and composite loyalty (Dai, 2002). According to Assael (1998), customer loyalty can be approached by behavioral and cognitive measures (Alonso, 2000). Whilst Dick and Basu (1994) focuses on the use of both attitude and behavior together to measure loyalty, it is also express the relationship between the relative attitude toward service provider and patronage behavior. Furthermore, Oliver (1997) believe that loyalty is composed of three components cognition, affect, and behavioral intention.

A distinction that has reached a general consensus is that loyalty is more than just a repeating as behavior; this is just a spurious loyalty, not a true one (Jacoby \& Chesnut 1978; Dick \& Basu, 1994; Alonso, 2000; Li, 2011). Therefore, the loyalty must be viewed as the relationship between attitude and behavior, which allows an integrated examination of customer loyalty antecedents and consequences (Dick and Basu, 1994). So that, Oliver (1999) suggested that attitude consists of the cognitive, affective, and conative component then the action comes as a complement to this attitude, then the real loyalty happen.

From the reviewing of literature review of customer loyalty (Dick and Basu, 1994; Dewitt, Nguyen, \& Marshall, 2008; Marshall, 2010; Li, 2011; Komunda \& Osarenkhoe, 2012; Kaur and Soch, 2013; Kakeeto-Aelen , Van Dalen, Van den Herik, \& Van de Walle, 2014; Cossío-Silva et al., 2016; Kamran-Disfani et al., 2017) the researchers find that most of this studies depend on two dimensions to measure customer loyalty; attitudinal loyalty and behavioral loyalty.

\section{A. Attitudinal Loyalty $(A C L)$}

According to Jacoby and Chestnut (1978), attitudinal loyalty is the consumer's psychological tendency toward same brand set and it is based on the consumer attitudes (Marshall, 2010). It is the extent of the customer's psychological attachments and attitudinal advocacy towards the service provider and his/her desire to recommend its services to others, effectively engaging in positive WOM behaviors (Rauyruen \& Miller, 2007; Jaiswal \& Niraj, 2011; Kaur \& Soch, 2013). Therefore, it refers to the positive personal attitude held by 
customers toward a particular product, a service, or a retailer (Cossío-Silva et al., 2016; Kamran-Disfani et al., 2017).

Attitudinal loyalty reflects a higher order customer's commitment towards a service provider, which can sometimes generate a superior return for the firm through positive WOM intentions, a willingness to pay, and an increased likelihood of future patronage (DeWitt et al., 2008). It is also defined as positive influence on the desire to keep the relationship with service firm alive and well (Komunda \& Osarenkhoe, 2012). Thus, the attitudinal loyalty is an indication of the behavioral side of customer loyalty (Donio, Massari, and Passiante, 2006), and it helps in reducing the switching behavior (Caceres \& Paparoidamis, 2007).

\section{B. Behavioral loyalty $(B C L)$}

In the late 1960s, customer loyalty started to be studied looking only at its behavioral perspective - i.e. just looking at the repeated purchases (Li, 2011). Zeithaml, Berry, and Parasuraman (1996) suggested a multidimensional framework measure the behavioral intentions of customers in the services sector. He saw that loyal customers have high intentions to repurchase and less sensitivity to prices, they are more likely to provide feedback, and have not intention to shift to another service provider.

According to Ehrenburg (1988), behavioral loyalty reflects customer's actions based upon past purchases or the probability of future purchases given past purchase behavior (Marshall, 2010). It is also referred to the repeated transactions (or percentage of total transactions in the category, or total expenditures in the category) and sometimes can be measured by observational methods (Komunda and Osarenkhoe, 2012). It refers to the readiness of customers to repurchase or to deal again with the service provider, and maintain the relationship with it (Kaur and Soch, 2013). Therefore, it considered the method of behaving and repeated purchasing its indicator (Cossío-Silva et al., 2016) as well as it refers to repeat purchases by a customer from a specific retailer (Kamran-Disfani et al., 2017). Moreover, it described as the repeat using of a particular service or product over time (Inoue, Funk, and McDonald, 2017).

\subsection{Service Recovery Strategies and Customer Loyalty}

Komunda and Osarenkhoe (2012) and Yaya et al. (2013) hold that service recovery activities drive the customer towards positive WOM behavior, and spreading goodwill for the service provider. Mccollough et al., (2000) study also refer that effective service recovery can increase customer loyalty. Moreover, Chou (2015) mentioned that some kind of service recovery (apology and compensation) influence positively on customer loyalty (both attitudinal and behavioral). Accordingly, we proposed the following hypothesis:

H1: SR strategies have a significant positive influence on both a) Attitudinal and b) Behavioral loyalty.

\subsection{Service Recovery Strategies and Service Recovery Satisfaction}

Kim (2007) suggests that apology and compensation as SR strategies positively affect customer satisfaction, while there was no significant effect of problem solving on customer satisfaction. Furthermore, this study found that compensation is more effective than an apology in influencing customer satisfaction. Ikponmwen, (2011) found that both apologizing, providing explanations, and giving a follow-up can have a positive, significant, influence on SRS. As a whole service recovery positively affects customer satisfaction (Duffy, Miller,and Bexley, 2006; Komunda and Osarenkhoe, 2012; Yaya et al., 2013; Kandulapati and Bellamkonda, 2014; Stratemeyer, Geringer,and Canton, 2014). Wirtz and Mattila (2004) found a significant effect on SRS by compensation, the speed of recovery, and apologizing. So that, we proposed the next hypothesis:

H2: SR strategies have a positive effect on service recovery satisfaction.

\subsection{Service recovery Satisfaction and Customer Loyalty}

Several studies showed that the complainant's level of SRS significantly affects CL (Kau \& Loh, 2006; De Matos, Henrique, and de Rosa, 2013; Liat, Mansori, Chuan, \& Imrie, 2017; Cambra-Fierro et al., 2017; Chen \& Wang, 2016). Furthermore, the customer satisfaction has a positive effect on behavioral loyalty (Kim, 2007; Doaei et al., 2011; Pi \& Huang, 2011; Nakhleh, 2012; Komunda \& Osarenkhoe, 2012; Yaya et al., 2013; Chinomona \& Dubihlela, 2014; Kakeeto-Aelen et al., 2014). In addition, customer satisfaction positively affects attitudinal loyalty (Banyte, Tarutè, \& Taujanskyte, 2014). De Matos, Vargas Rossi, Teixeira Veiga, and Afonso Vieira, (2009); Lii and Lee, (2012) reached to that SRS has a significant positive influence on both WOM and repurchase intentions. In addition, it has a significant positive influence on CL as a whole (Kim, Jung-Eun Yoo, and Lee, 2012; Sousa and Voss, 2009).

Some researchers have studied how SRS mediates the relationship between SR strategies and CL (Yaya et al., 2013); others studied the direct influence of SR as a whole and WOM communications and repurchase intentions 
(Komunda \& Osarenkhoe, 2012), while others studied some of SR strategies on customer loyalty as a whole (Yaya et al., 2013). On the other side, some researcher studied the direct influence of various SR strategies on SRS. In addition, most researchers studied the direct link between customer satisfaction and CL as a whole or with its dimensions. Moreover, Yaya et al., (2013) also indicated that customer satisfaction mediates the positive direct relationship between the strategies of the service recovery (contact and responsiveness) and customer loyalty as a whole. Depending on the above, we proposed that SRS mediates the relationship between seven strategies of SR and customer loyalty with its two dimensions. So that, we proposed the following hypothesis.

H3: Service recovery satisfaction has a positive effect on both a) Attitudinal and b) Behavioral loyalty.

H4: Service recovery satisfaction mediates the positive effect of SR strategies on a) Attitudinal and b) Behavioral loyalty.

Our proposed model illustrated in the Figure 1.

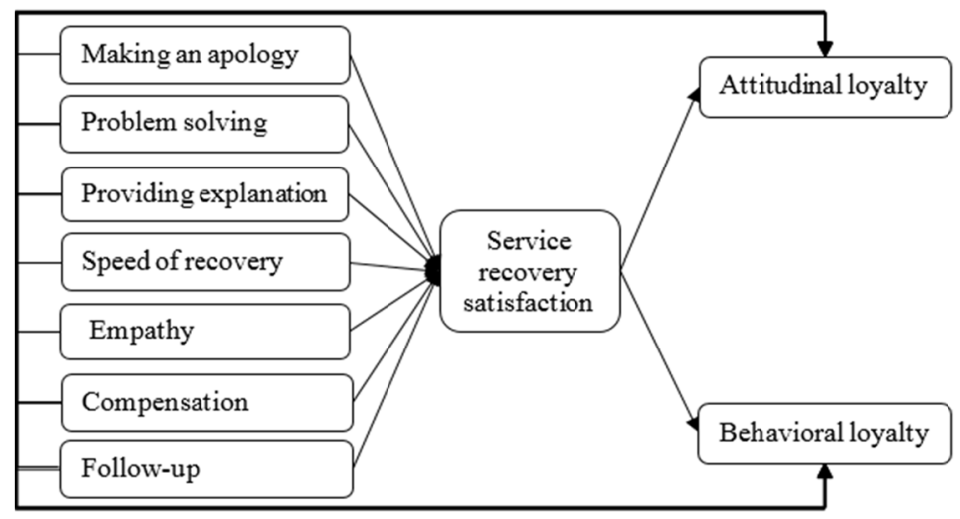

Figure 1. The proposed model.

\section{Method}

\subsection{Measures}

In order to investigate the quality of SR, we have combined several measures developed by Boshoff (1999), Boshoff et al. (2005), Kau and Loh (2006), Kim (2007), Liao (2007), Del Río-Lanza, Vázquez-Casielles, and Díaz-Martín (2009) in a 30-item scale. We measure SRS with a 13 items scale based on those defined in previous literature (Del Río-Lanza et al., 2009; Kim et al., 2012; Li-hua, 2012; Kaur \& Soch, 2013; Wen \& Chi, 2013). Finally, we measure CL on an eight items scale based on previous ones (Kim, 2007, Dewitt et al., 2008, Kim et al., 2012; Kaur \& Soch, 2013). These new measures consist of 30 items for SR strategies, 13 for service recovery satisfaction; and 8 for customer loyalty ranked on a 5-point Likert scale (starting from 5 - fully agree to 1- fully disagree).

The initial copy of our questionnaire has presented to some scholar in the area of marketing to make sure of the measurement validity. In addition, it has been administered to a group of sample units and some of the professionals in the field of Internet services to verify if the target audience easily understood the various scales. Then, the researchers modified the questionnaire according to the various observations, and we compiled data from sample units. In order to reach for a broader sample, the researchers used an online survey matching the conditions applied to similar studies. Following Saunders, Saunders, Lewis, and Thornhill, (2011: p. 364) questionnaire was administered online for four weeks. According to the related literature the answer distortion by investigator bias are weak, more so when the sample size is large and geographically dispersed.

\subsection{Sample and Data Collection}

In order to verify our hypothesis, we are collecting the data from a sample of high-speed ADSL internet services users in the Dakahlia governorate, in Egypt; the online survey was administered using a form designed on Google drive. The data collection procedure was made of three stages:

1. To ensure accuracy in data collection, the researcher put two filtering question at the beginning of the questionnaire and some reverse questions. The first question asks the user about the place of current residence whether he/she is from Dakahlia governorate or from another governorate. In case the answer is "Dakahlia", the user continues the questionnaire and sees the rest of the items. If the answer was another 
governorate, the user was thanked and the questionnaire discontinues. The second question asks the user if he was ever exposed to a problem with his, or hers, current Internet service provider and the survey did continue only when the answer was yes. In case the answer is "yes", the user continues to see the rest of the items.

2. The researchers also put two reverse questions number to ensure the accuracy and honesty of the user when answering the questionnaire.

3. We have distributed the questionnaire on the service provider's fan-pages, their sites and forums service providers.

The number of fully responded questionnaires is 430 . The respondent characteristics of study sample illustrated in the Table 2.

Table 2. Respondent characteristics

\begin{tabular}{lll}
\hline Characteristics & Number & $\mathbf{( \% )}$ \\
\hline Gender & & \\
Male & 256 & 59.5 \\
Female & 174 & 40.5 \\
Age & & \\
$<20$ year & 38 & 8.8 \\
20 to $<35$ year & 351 & 81.6 \\
35 year and older & 41 & 9.6 \\
Internet provider & & \\
TE-DATA & 304 & 70.7 \\
Vodafone & 58 & 13.5 \\
Etisalat & 39 & 9.1 \\
LinkDSL (Orange) & 29 & 6.7 \\
Subscription category & & \\
1 Mb and less & 266 & 61.8 \\
2 Mb & 176 & 27 \\
4 Mb and more & 48 & 11.2 \\
\hline
\end{tabular}

\section{Analysis and Results}

The PLS-SEM approach was used to analyze our data collected. We have chosen PLS as it does not necessitate the normal distribution of data. As well as, it is considered an appropriate approach to use when analyzing a large number of constructs, and it is very robust against multicollinearity (Cassel, Hackl, and Westlund, 2000; Yaya et al., 2013; Wang, Yeh, and Liao, 2013).

In addition, PLS-SEM guarantees optimum prediction accuracy because latent variable scores were computed such that the reliability indices of the indicators and the R-squared of the latent variables are maximized. As well as, it provides a suitable approach comprised of two steps where all measurement models were tested for their psychometric properties in the first step, while the second one concentrates on testing the study hypotheses (Fornell \& Cha, 1994).

Sarstedt, Ringle, Smith, Reams, and Hair (2014) pointed that three criteria should be used to evaluate the quality of PLS models namely R2, Q2, and the path coefficients. In addition, the following measures used to evaluate the overall fit of the proposed models; APC, ARS, AVIF, and GoF. According to Kock (2012), APC and ARS are considered significant if $\mathrm{P}<0.05$ as well as AVIF $<5$. The values $\geq 0.1, \geq 0.25$, and $\geq 0.36$ refers a small, medium, and large goodness of fit (GoF) index for the proposed model (Tenenhaus, Amato, and Esposito Vinzi, 2004).

\subsection{Measurement Model}

Klarner, Sarstedt,Hoeck, and Ringle (2013) stated that the major step in the model evaluation has been to test its reliability (i.e., the construct measure's indicator reliability and internal consistency reliability) and validity (i.e., convergent validity and discriminant validity).

According to Hair, Hult, Ringle, and Sarstedt (2014), the indicators we have used considered reliable as all items loadings are over 0.50 . The internal consistency of each construct also supported as both the Cronbach's $\alpha$ s and Composite Reliability (CR) for the main latents were higher than 0.7 (Fornell \& Larcker, 1981). We have a convergent validity as all constructs' Average Variance Extracted (AVE) are over 0.50 (Fornell \& Larcker 1981) 
as illustrated in Table 3.

As shown in table 4, the discriminant validity is confirmed as the (AVE) square root for each construct is higher than its correlations with other constructs. So that, our proposed model has an appropriate reliability, convergent, and discriminant validity.

Table 3. Measurement statistics of construct scales

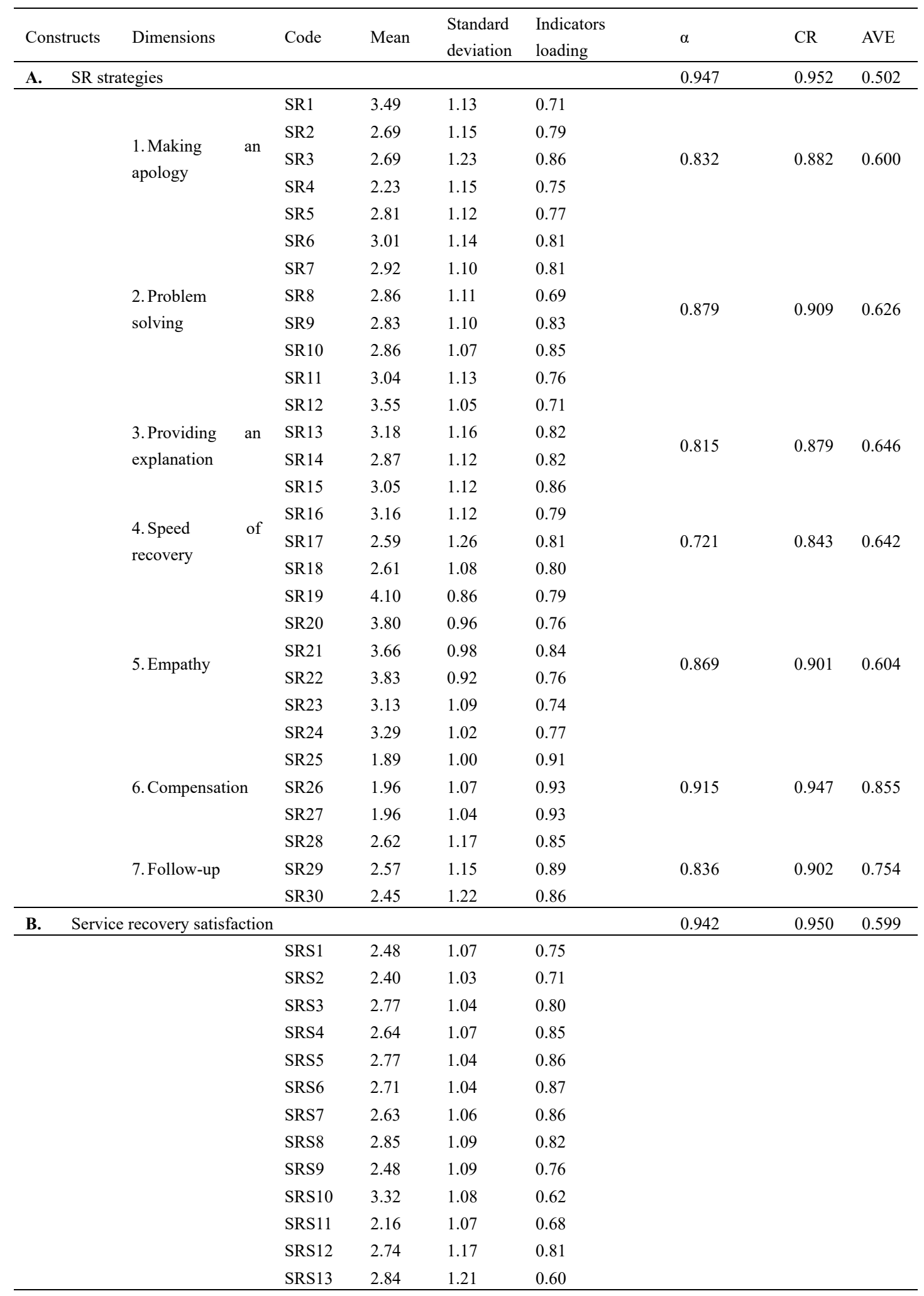




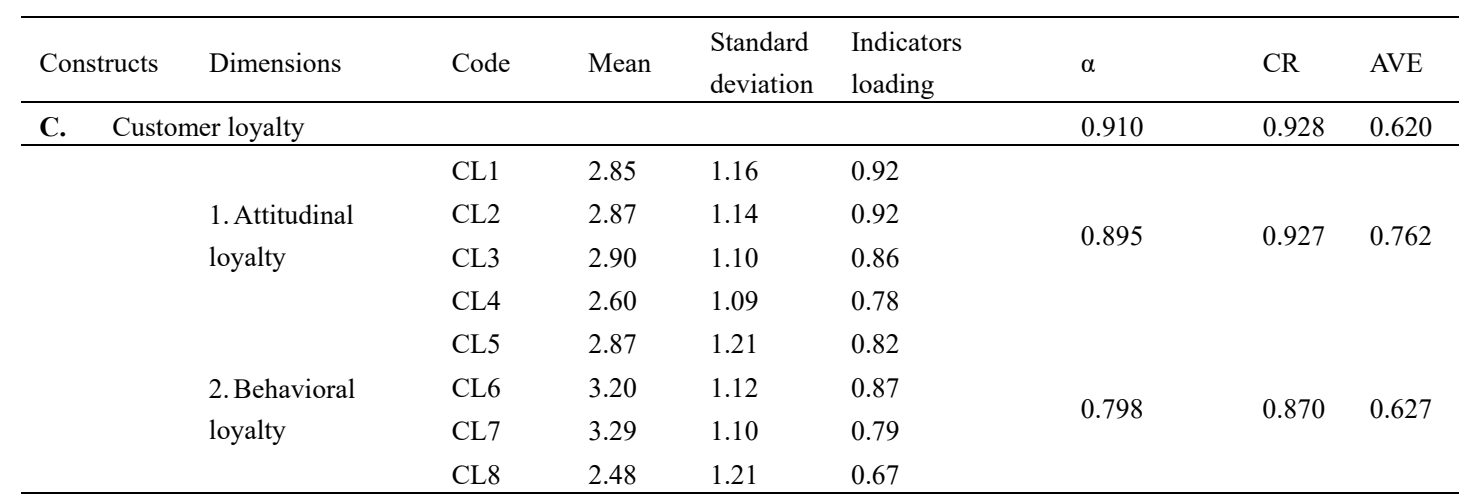

Table 4. Discriminant validity of the correlations between constructs

\begin{tabular}{|c|c|c|c|c|c|c|c|c|c|c|}
\hline & MA & PS & PE & SPE & EMP & COM & FOL & SRS & ACL & BCL \\
\hline MA & $(0.775)$ & & & & & & & & & \\
\hline PS & 0.611 & $(0.791)$ & & & & & & & & \\
\hline PE & 0.552 & 0.753 & $(0.804)$ & & & & & & & \\
\hline SPE & 0.472 & 0.634 & 0.620 & $(0.801)$ & & & & & & \\
\hline EMP & 0.508 & 0.659 & 0.667 & 0.595 & $(0.777)$ & & & & & \\
\hline COM & 0.478 & 0.415 & 0.383 & 0.414 & 0.279 & $(0.925)$ & & & & \\
\hline FOL & 0.473 & 0.475 & 0.471 & 0.448 & 0.404 & 0.604 & $(0.868)$ & & & \\
\hline SRS & 0.559 & 0.761 & 0.709 & 0.660 & 0.587 & 0.581 & 0.612 & $(0.774)$ & & \\
\hline ACL & 0.438 & 0.586 & 0.551 & 0.436 & 0.483 & 0.409 & 0.467 & 0.720 & $(0.873)$ & \\
\hline BCL & 0.362 & 0.507 & 0.475 & 0.382 & 0.478 & 0.349 & 0.380 & 0.624 & 0.782 & $(0.792)$ \\
\hline
\end{tabular}

\subsection{Structural Model}

It describes the causal relationships between constructs as well as it purposes to examine the suggested hypotheses. The approach of Klarner et al. (2013) has been used to perform the step-by-step analysis in order to test the proposed hypotheses from 1 to 4 .

Firstly, we examined the direct relations between constructs (H1, 2, and 3). Subsequently, in the second step, we evaluated the PLS path model as a whole and, more specifically, we examined the role of mediator variable (H4). Tables 5 and 6 summarize the path coefficients and the significant levels we have got.

The results reports that the value of $\mathrm{APC}=0.134$ and the value of $\mathrm{ARS}=0.634$, and $\mathrm{AVIF}$ value $=2.422$, in addition, $\mathrm{GoF}=0.652$. Therefore, our proposed model was classified as a "large" model fit.

In step 1 , we have found that hypothesis $\mathrm{H1a}$ is partially supported as $\mathrm{p}$. solving $(\beta=0.288, \mathrm{p}<0.001$ ), explanation $(\beta=0.140, p=0.002)$, showing empathy $(\beta=0.101, p=0.017)$, compensation $(\beta=0.118, p=0.007)$, and follow-up ( $\beta=0.140, p=0.002)$ have a significant influence on ACL, while speed, and making an apology have no significant effect.

Hypotheses H1b is also partially supported as p. solving $(\beta=0.247$, p-value $<0.001)$, explanation $(\beta=0.081, p$ $=0.046)$, showing empathy $(\beta=0.225, \mathrm{p}=<0.001)$, compensation $(\beta=0.132, \mathrm{p}=0.003)$, and follow-up $(\beta=$ $0.085, p=0.037$ ) have a significant influence on $B C L$, while speed, and making an apology have no significant effect.

Hypotheses $\mathrm{H} 2$ partially confirmed as the SR strategies without a significant effect on SRS were making apologies $(\beta=-0.015, \mathrm{p}<0.378)$ and empathy $(\beta=0.025, \mathrm{p}<0.229)$. As well as, the results show that SRS has a direct influence on both ACL $(\beta=0.721, p<0.001)$ and BCL $(\beta=0.628, p<0.001)$. So, hypotheses H3a and $\mathrm{H} 3 \mathrm{~b}$ are fully supported. 
Table 5. The results of direct paths

\begin{tabular}{|c|c|c|c|c|c|}
\hline & & & & & \\
\hline $\mathbf{H}$ & Predictor variables & $\begin{array}{l}\text { Dependent } \\
\text { Variables }\end{array}$ & $\begin{array}{l}\text { Path } \\
\text { coefficients }\end{array}$ & P-value & Results \\
\hline H1a & Apology & $\mathrm{ACL}$ & 0.059 & 0.110 & \multirow{7}{*}{ Partially supported } \\
\hline H1a & P. Solving & ACL & $0.288 * *$ & $<0.001$ & \\
\hline $\mathrm{H} 1 \mathrm{a}$ & Explanation & $\mathrm{ACL}$ & $0.140 * *$ & 0.002 & \\
\hline H1a & Speed & ACL & -0.027 & 0.285 & \\
\hline H1a & Empathy & ACL & $0.101^{*}$ & 0.017 & \\
\hline $\mathrm{H} 1 \mathrm{a}$ & Compensation & ACL & $0.118 * *$ & 0.007 & \\
\hline H1a & Follow-Up & ACL & $0.140 * *$ & 0.002 & \\
\hline $\mathrm{H} 1 \mathrm{~b}$ & Apology & BCL & 0.007 & 0.443 & \multirow{7}{*}{ Partially supported } \\
\hline $\mathrm{H} 1 \mathrm{~b}$ & P. Solving & BCL & $0.247 * *$ & $<0.001$ & \\
\hline $\mathrm{H} 1 \mathrm{~b}$ & Explanation & $\mathrm{BCL}$ & $0.081^{*}$ & 0.046 & \\
\hline $\mathrm{H} 1 \mathrm{~b}$ & Speed & $\mathrm{BCL}$ & -0.040 & 0.204 & \\
\hline $\mathrm{H} 1 \mathrm{~b}$ & Empathy & $\mathrm{BCL}$ & $0.225 * *$ & $<0.001$ & \\
\hline $\mathrm{H} 1 \mathrm{~b}$ & Compensation & $\mathrm{BCL}$ & $0.132 * *$ & 0.003 & \\
\hline $\mathrm{H} 1 \mathrm{~b}$ & Follow-Up & BCL & $0.085^{*}$ & 0.037 & \\
\hline $\mathrm{H} 2$ & Apology & SRS & -0.015 & 0.378 & \multirow{7}{*}{ Partially supported } \\
\hline $\mathrm{H} 2$ & P. Solving & SRS & $0.354 * *$ & $<0.001$ & \\
\hline $\mathrm{H} 2$ & Explanation & SRS & $0.168 * *$ & $<0.001$ & \\
\hline $\mathrm{H} 2$ & Speed & SRS & $0.157 * *$ & $<0.001$ & \\
\hline $\mathrm{H} 2$ & Empathy & SRS & 0.025 & 0.299 & \\
\hline $\mathrm{H} 2$ & Compensation & SRS & $0.213 * *$ & $<0.001$ & \\
\hline $\mathrm{H} 2$ & Follow-Up & SRS & $0.151 * *$ & $<0.001$ & \\
\hline $\mathrm{H} 3 \mathrm{a}$ & SRS & ACL & 0.721 & $<0.001 * *$ & \multirow{2}{*}{ Fully Supported } \\
\hline $\mathrm{H} 3 \mathrm{~b}$ & SRS & $\mathrm{BCL}$ & 0.628 & $<0.001 * *$ & \\
\hline
\end{tabular}

$* \mathrm{P}<0.05, * * \mathrm{P}<0.01$

As shown in table 6 , and according to step two of analysis, SRS completely mediates the relationship between $p$. solving $(\beta=0.228, p<0.001)$, explanation $(\beta=0.108, p<0.001)$, compensation $(\beta=0.138, p<0.001)$, follow-up $(\beta=0.097, p=0.002)$ and $A C L$, which partially supported $\mathrm{H} 4 \mathrm{a}$ and $\mathrm{H} 4 \mathrm{~b}$.

Table 6. Indirect influence of SR strategies on ACL, BCL

\begin{tabular}{|c|c|c|c|c|c|c|c|c|}
\hline \multirow[b]{2}{*}{$\mathrm{H}$} & \multirow{2}{*}{$\begin{array}{l}\text { Predictor } \\
\text { variables }\end{array}$} & \multirow{2}{*}{$\begin{array}{l}\text { Mediator } \\
\text { variable }\end{array}$} & \multirow{2}{*}{$\begin{array}{l}\text { Dependent } \\
\text { Variables }\end{array}$} & \multicolumn{3}{|l|}{ Path coefficients } & \multirow[b]{2}{*}{ Results } & \multirow{2}{*}{$\begin{array}{l}\text { Type } \\
\text { mediating } \\
\text { effects }\end{array}$} \\
\hline & & & & $\begin{array}{l}\text { Direct with } \\
\text { mediating effect }\end{array}$ & Indirect & Total & & \\
\hline $\mathrm{H} 4 \mathrm{a}$ & Apology & \multirow{7}{*}{ SRS } & $\mathrm{ACL}$ & 0.046 & -0.010 & 0.037 & \multirow{7}{*}{$\begin{array}{l}\text { Partially } \\
\text { supported }\end{array}$} & No med. \\
\hline $\mathrm{H} 4 \mathrm{a}$ & P. Solving & & ACL & 0.049 & $0.228 * *$ & $0.277 * *$ & & Full med. \\
\hline $\mathrm{H} 4 \mathrm{a}$ & Explanation & & ACL & 0.034 & $0.108 * *$ & $0.142 * *$ & & Full med. \\
\hline $\mathrm{H} 4 \mathrm{a}$ & Speed & & ACL & -0.126 & 0.101 & -0.025 & & No med. \\
\hline $\mathrm{H} 4 \mathrm{a}$ & Empathy & & ACL & $0.088^{*}$ & 0.016 & $0.104 *$ & & No med. \\
\hline $\mathrm{H} 4 \mathrm{a}$ & Compensation & & ACL & 0.023 & $0.138 * *$ & $0.160 * *$ & & Full med. \\
\hline $\mathrm{H} 4 \mathrm{a}$ & Follow-Up & & ACL & 0.054 & $0.097 * *$ & $0.151^{* *}$ & & Full med. \\
\hline $\mathrm{H} 4 \mathrm{~b}$ & Apology & \multirow{7}{*}{ SRS } & BCL & 0.015 & -0.009 & 0.006 & \multirow{7}{*}{$\begin{array}{l}\text { Partially } \\
\text { supported }\end{array}$} & No med. \\
\hline $\mathrm{H} 4 \mathrm{~b}$ & P. Solving & & BCL & 0.018 & $0.203 * *$ & $0.220 * *$ & & Full med. \\
\hline $\mathrm{H} 4 \mathrm{~b}$ & Explanation & & BCL & 0.007 & $0.096 * *$ & $0.103 *$ & & Full med. \\
\hline $\mathrm{H} 4 \mathrm{~b}$ & Speed & & BCL & -0.122 & 0.090 & -0.033 & & No med. \\
\hline $\mathrm{H} 4 \mathrm{~b}$ & Empathy & & BCL & $0.217 * *$ & 0.015 & $0.231 * *$ & & No med. \\
\hline $\mathrm{H} 4 \mathrm{~b}$ & Compensation & & BCL & 0.011 & $0.122 * *$ & $0.133^{* *}$ & & Full med. \\
\hline $\mathrm{H} 4 \mathrm{~b}$ & Follow-Up & & BCL & -0.005 & $0.087^{*}$ & $0.082 *$ & & Full med. \\
\hline
\end{tabular}

Looking at the mediating effects of SRS, our results indicates that SRS completely mediates the positive link between $\mathrm{p}$. solving $(\beta=0.203, \mathrm{p}<0.001)$, explanation $(\beta=0.096, \mathrm{p}=0.002)$, compensation $(\beta=0.122, \mathrm{p}<0.001)$, 
follow-up ( $\beta=0.087, \mathrm{p}=0.006)$ and BCL.

Our findings showed that the $\mathrm{R}^{2}$ value of ACL and BCL were 0.557 and 0.437 respectively, which indicates that both SR strategies and SRS collectively explains about $56 \%$ of the difference in ACL and explains about $44 \%$ of the difference in BCL. Moreover, our results give an SRS R ${ }^{2}$ of 0.720 , which refers to that SR strategies explain the difference in SRS by $72 \%$. The $\mathrm{Q}^{2}$ value of ACL $(0.540)$, BCL $(0.429)$, and SRS $(0.738)$, which meaning that our proposed model has large predictive relevance.

\section{Discussion}

The currents study aims to provide some valuable and practical insights for internet providers and their managers to improve their performance through identifying the relationship between SR strategies, SRS, and CL as well as determine the mediating role of SRS in the service recovery-customer loyalty relationship.

\subsection{Service Recovery and Customer Loyalty}

Our findings revealed that all SR strategies, except making apology and speed of recovery, affect ACL. This seems logical since the Internet service providers often make an apology to customers in case of a customer complaint about poor service. They also implement speed of recovery, however, their efforts cease at these two things. They do not solve customer's problems, compensate them, or follow up afterward. Therefore, the other strategies of the service recovery are the most important from their point of view. This is consistent with the result of the interviews in the pilot study when customer described Internet service providers with the famous saying "A honey tongue, a heart of gall". Consequently, if these companies did not pay more attention to solving customer's problems, compensate them, and follow-up; such customers will not recommend others to deal with such companies or deny their positive aspects in front of others.

The study also indicates that all SR strategies influence BCL except making apology and speed of recovery. It seems logical as behavioral loyalty is based on re-purchase or dealing with that company repeatedly and experiencing new services in the near future. Therefore, the most influential strategies on this kind of loyalty were problem-solving, providing explanations, empathy, civility in dealing with customers, as well as offering material and moral compensation for any damage suffered resulting from poor service and follow-up the customer after service recovery. If the companies under consideration do not pay attention to such strategies, customers we will not deal with them again.

The two previous results agreed partially with results in the literature (Mccollough et al., 2000; Komunda and Osarenkhoe, 2012), which refers to that SR strategies influence positively on customer loyalty.

\subsection{Service Recovery and Service Recovery Satisfaction}

The study also found that solve the customer problems, explanation, recovery speed, compensate, and follow up them have significant positive effects on service recovery satisfaction. We hold that customers see making an apology, being empathic, and being polite as one of the foundations for a profitable relationship with the service provider. When its employees are not able to provide this basic level of service, customers feel not obliged to continue dealing with the company, especially when there are valid alternatives. Consequently, the more companies focus on solving customers problems, answering their questions, responding promptly, compensating them, and follow-up the service, the higher the level of satisfaction with the process of service recovery in those companies.

Our results are consistent with various studies. It consistent with Kim (2007) finding that compensation is an effective strategy in increasing the customer's satisfaction of service recovery. At the same time, our results are not coherent with Kim's (2007) ones as he found no significant impact of problem-solving strategy on service recovery satisfaction despite the similarity of application sector. They are consistent with Wirtz and Mattila (2004) in finding a positive significant effect on both compensation and speed of recovery combined them with making an apology have a significant impact on SRS. Our findings agreed with Ikponmwen (2011), on his study on hotel sector, who mentioned that apologizing, explanation and feedback have a positive influence on SRS. Our findings are also consistent with Komunda and Osarenkhoe (2012) and Yaya et al. (2013) which indicate that service recovery as a whole significantly affects service recovery satisfaction. The results are in the line with Mostafa et al. (2014) as both problem solving and recovery speed positively impacts on SRS, as well as empathy not have an impact on SRS.

Conversely, Our results not consistent with Kim (2007) in the non-significant influence of problem solving on SRS. In addition, with regarding Egyptian context, it does not agree with Mostafa et al. (2014) foundations in that apology have a significant impact on SRS, as well as compensation, explanation, follow up not have an impact on SRS. These results motivated us to do more studies at this point especially in eastern communities or 
in Egyptian context for another type of services. In addition, the main previous results come in the line with Levesque and McDogugall (2000) overview, who confirmed that using apologizing alone is considered unproductive especially in a core service failure.

\subsection{Service Recovery Satisfaction and Customer Loyalty}

Our findings supporting the big role of service recovery satisfaction in influencing both the customer's behavioral and attitudinal loyalty - while the largest effect is on attitudinal loyalty. The findings can be interpreted in the lights of Yüksel and Rimmington (1998) who stated that customer satisfaction is essential to increase customer retention, to create the intentions of recommending the company to others, and to encourage positive communication i.e. to build customer loyalty. Therefore, the service provider must evaluate the level of satisfaction of its customers constantly and applies that knowledge to improve the delivery of services usually achieves significant competitive advantage.

Companies should pay more attention to service recovery strategies that help to achieve service recovery satisfaction because of its significant impact on both attitudinal and behavioral loyalty. The higher the level of SR satisfaction, the more they are inclined to mention the advantages of dealing with the company in front of others and recommend them to do the same. They also will deal with the company again in the future and they will be more likely try the new services announced by the company in the future. Both of these consequences will boost the profitability of these companies. The previous result is consistent with several studies (Kau and Loh, 2006; Kim, 2007; Doaei et al., 2011; Pi and Huang, 2011; Kim et al., 2012; Nakhleh, 2012; Sousa and Voss, 2009; Komunda and Osarenkhoe, 2012; Lii and Lee, 2012; De Matos et al., 2013; Yaya et al., 2013; Chinomona and Dubihlela, 2014; Kakeeto-Aelen et al., 2014; Liat et al., 2017; Cambra-Fierro et al., 2017; Chen and Wang, $2016)$ in that SRS positively affects customer loyalty.

\subsection{The Mediating Role of Service Recovery Satisfaction in the Service Recovery-Customer Loyalty Relationship}

Our results found that SRS completely mediated the positive effect of solving the customer problems, providing explanations, compensate and follow up them on both dimensions of customer loyalty.

We can say that the significant effect these service recovery strategies on attitudinal loyalty will increase when service recovery satisfaction mediates. We can explain this considering that when Internet providers solve customer's problems and provide an explanation as needed, and then compensate and follow-up, it will get a higher level of SRS and, consequently they will increase the level of attitudinal loyalty. The same can be held when looking at the mediating influence of SRS on the relationship between these strategies on behavioral loyalty. The previous results agreed with Yaya et al. (2013) in that SRS mediates the positive link between SR and CL.

\section{Conclusion}

The current study mainly estimates the link between the SR strategies, SRS and CL in the Internet service context. Prior studies confirmed that SR strategies considered a key predictor of CL. As well as, more recent studies show that SR dimensions directly affects SRS. In addition, SRS influences CL.

In this work, we move forward the existing knowledge on these topics, our findings confirmed that p. solving, explanation, empathy, compensation, and follow-up strategies influence on both attitudinal and behavioral loyalty directly. Moreover, our findings confirmed that SRS has a mediating role in the relationship between p.solving, explanation, recovery speed, compensation, follow-up strategies and both attitudinal and behavioral loyalty. This highlights that internet service providers must focus more on previous strategies to improve the customer satisfaction and loyalty consequently.

We have not a significant influence of apologizing strategy on CL directly and indirectly via SRS. So that, this strategy not considered an effective one unless it has coupled with some of other SR strategies. This is probably linked to the importance of the Internet service in the modern society so consumers consider any form of service failures as a failure in a core service and, in line with the results of Levesque and McDogugall (2000), they do not want the company to apologize but they ask it to solve the problem and they want to be compensated for the disservice.

The current study provides numerous managerial implications as follows. In general, we advise managers to think like the customer, respect and pamper their customer, and exceed customer's expectation because of its effect on customer retention. Then, managers should be proactive in providing effective service recovery procedures; these should be designed and taught to employees. Finally, companies should understand that even if problem solving is considered as the most relevant SR strategy, the customer expects it, so their SRS will increase when the problem is dealt with quickly, as well as manager should focus on a follow-up strategy to 
increase the service firm image.

This study provides further research directions as follows. First, we classified service recovery strategies to investigate the effects of each strategy on customer loyalty into seven types: apology, p. solving, explanations, recovery speed, empathy, compensation, and follow-up. As the results show, both apologizing and recovery speed have not a significant influence on customer loyalty. Therefore, future researchers may want to compare more service recovery types with each other's to investigate more precisely each dimension of customer loyalty for example apology $\times$ compensation or empathy $\times$ providing explanations. As well as, future researchers may want to compare tangible service recovery strategies (e.g. compensation, problem-solving, speed of recovery and follow-up) with intangible/ psychological service recovery strategies (e.g. apology, empathy and providing explanations) to investigate more precisely each dimension of customer loyalty. In addition, future researchers may want to classify some recovery strategies to levels such as levels of compensation and apology... etc., this may generate different responses for respondents.

Second, it focuses on examining the influence of SR strategies on positive consequences like customer loyalty, so that, further studies may need to explain its influence on some negative consequences like customer switching intentions. In addition, we proposed according to expectation theory that value co-creation behaviors such as participation and citizenship behaviors may have meaningful findings to examine the relationship between SR justice and consumer's behavioral consequences. Also, we expect that, service recovery strategies may be influenced directly on some issues related to providers brand after many times of failures, so, future researchers may want to explore its effect on brand credibility and corporate image in other sectors, which have many compatible alternatives with same quality service levels like five star hotels and airlines.

Third, we not found a significant impact of apology and empathy on customer loyalty attributes, so, further research may be focused on reinvestigating the same study in other services context, which has more face-to-face interaction such as hotel industry. This may generate different responses for customers. Fourth, our study ignored the cross-culture issue so applying the same model in developing and developed countries may give new directions for further researches. Finally, we concentrate on complainants customers who suffer from service failure situation, so making a comparison between two models for complainants and non-complainants customers could give meaningful results.

\section{References}

Andersson, E., Graselius, H., \& Nilsson, K. (2005). Service Recovery a Study of the Complaint Handling Process at Hotel Gothia Towers. Master thesis, Goteborg University.

Andreassen, T. W. (2000). Antecedents to satisfaction with service recovery. European Journal of Marketing, 34(1/2), 156-175. http://dx.doi.org/10.1108/03090560010306269

Ashill, N. J., Carruthers, J., \& Krisjanous, J. (2005). Antecedents and outcomes of service recovery performance in a public health-care environment. Journal of Services Marketing, 19(5), 293-308. http://dx.doi.org/10.1108/08876040510609916.

Banytė, J., Tarutè, A., \& Taujanskytè, I. (2014). Customer engagement into value creation: Determining factors and relations with loyalty. Engineering Economics, 25(5), 568-577. http://dx.doi.org/10.5755/j01.ee.25.5.8402

Banytė, J., Tarutė, A., \& Taujanskytè, I. (2014). Customer engagement into value creation: Determining factors and relations with loyalty. Engineering Economics, 25(5), 568-577.

Battaglia, D., Borchardt, M., Afonso Sellitto, M., \& Medeiros Pereira, G. (2012). Service recovery: a method for assessing performance. Business Process Management Journal, 18(6), 949-963. http://dx.doi.org/10.1108/14637151211283366

Bennett, R., \& Rundle-Thiele, S. (2002). A comparison of attitudinal loyalty measurement approaches. Journal of Brand Management, 9(3), 193-209. http://dx.doi.org/10.1057/palgrave.bm.2540069

Blodgett, J. G., Granbois, D. H., \& Walters, R. G. (1993). The effects of perceived justice on complainants' negative word-of-mouth behavior and repatronage intentions. Journal of Retailing, 69(4), 399-428.

Boshoff, C. (1999). RECOVSAT: An instrument to measure satisfaction with transaction-specific service recovery. Journal of service research, 1(3), 236-249.

Boshoff, C., Hoogendoorn, P. M., \& van der Kraan, Y. (2005). A differentiated approach to service recovery. Nyenrode Research Group working paper series, (05-03). 
Caceres, R.C., \& Paparoidamis, N.G. (2007). Service quality, relationship satisfaction, trust, commitment and business-to-business loyalty. European Journal of Marketing, 41(7/8), 836-867. http://dx.doi.org/10.1108/03090560710752429

Cambra-Fierro, J., Pérez, L., \& Grott, E. (2017). Towards a co-creation framework in the retail banking services industry: Do demographics influence? Journal of Retailing and Consumer Services, 34, 219-228. http://dx.doi.org/10.1016/j.jretconser.2016.10.007

Cassel, C. M., Hackl, P., \& Westlund, A. H. (2000). On measurement of intangible assets: A study of robustness of partial least squares. Total Quality Management, 11(7), 897-907. http://dx.doi.org/10.1080/09544120050135443

Chang, C. C. (2004). The effect of choice and perceived control on customer satisfaction: The psychology of service recovery, Purdue University.

Chen, C. F., \& Wang, J. P. (2016). Customer participation, value co-creation and customer loyalty-A case of airline online check-in system. Computers in Human Behavior, 62, 346-352. http://dx.doi.org/10.1016/j.chb.2016.04.010.

Cheung, FYM, \& To, WM (2016). A customer-dominant logic on service recovery and customer satisfaction. Management Decision, 54(10), 2524-2543. http://dx.doi.org/10.1108/MD-03-2016-0165

Choi, B., \& La, S. (2013). The impact of corporate social responsibility (CSR) and customer trust on the restoration of loyalty after service failure and recovery. Journal of Services Marketing, 27(3), 223-233. http://dx.doi.org/10.1108/08876041311330717

Chou, P. F. (2015). An analysis of the relationship between service failure, service recovery and loyalty for Low Cost Carrier travelers. Journal of Air Transport Management, 47, 119-125. http://dx.doi.org/10.1016/j.jairtraman.2015.05.007

Cossío-Silva, F. J., Revilla-Camacho, M. Á., Vega-Vázquez, M., \& Palacios-Florencio, B. (2016). Value co-creation and customer loyalty. Journal of Business Research, 69(5), 1621-1625. http://dx.doi.org/10.1016/j.jbusres.2015.10.028.

Dai, Y. D. (2002). Overall customer satisfaction, trust, and commitment in customer voluntary performance behaviors with travelers in lodging services. PhD dissertation, Pennsylvania State University.

Day, G. S. (1969). A two dimensional concept of brand loyalty. Journal of Advertising Research, 9, 29-35.

De Matos, C. A., Henrique, J. L., \& Alberto Vargas Rossi, C. (2007). Service recovery paradox: a meta-analysis. Journal of service research, 10(1), 60-77.

De Matos, C. A., Henrique, J. L., \&\& de Rosa, F. (2013). Customer reactions to service failure and recovery in the banking industry: the influence of switching costs. Journal of Services Marketing, 27(7), 526-538.

De Matos, C. A., Vargas Rossi, C. A., Teixeira Veiga, R., \& Afonso Vieira, V. (2009). Consumer reaction to service failure and recovery: the moderating role of attitude toward complaining. Journal of Services Marketing, 23(7), 462-475.

Del Río-Lanza, A. B., Vázquez-Casielles, R., \& Díaz-Martín, A. M. (2009). Satisfaction with service recovery: Perceived justice and emotional responses. Journal of Business Research, 62(8), 775-781. http://dx.doi.org/10.1016/j.jbusres.2008.09.015

Del Río-Lanza, A. B., Vázquez-Casielles, R., \& Díaz-Martín, A. M. (2009). Satisfaction with service recovery: Perceived justice and emotional responses. Journal of Business Research, 62(8), 775-781.

DeWitt, T., Nguyen, D. T., \& Marshall, R. (2008). Exploring customer loyalty following service recovery: The mediating effects of trust and emotions. Journal of Service Research, 10(3), 269-281.

Dick, A. S., \& Basu, K. (1994). Customer loyalty: toward an integrated conceptual framework. Journal of the Academy of marketing science, 22(2), 99-113.

Dimitriades, Z. S. (2006). Customer satisfaction, loyalty and commitment in service organizations: Some evidence from Greece. Management Research News, 29(12), 782-800. http://dx.doi.org/10.1108/01409170610717817

Donio', J., Massari, P., \& Passiante, G. (2006). Customer satisfaction and loyalty in a digital environment: an $\begin{array}{lllll}\text { empirical test. Journal of Consumer } & \text { Marketing, 23(7), 445-457. }\end{array}$ http://dx.doi.org/10.1108/07363760610712993 
Duffy, J. A. M., Miller, J. M., \& Bexley, J. B. (2006). Banking customers' varied reactions to service recovery strategies. International Journal of Bank Marketing, 24(2), 112-132. http://dx.doi.org/10.1108/02652320610649923

Eakuru, N., \& Mat, N. K. N. (2008). The application of structural equation modeling (SEM) in determining the antecedents of customer loyalty in banks in South Thailand. The Business Review, Cambridge, 10(2), 129-139.

Edvardsson, B., Johnson, M. D., Gustafsson, A., \& Strandvik, T. (2000). The effects of satisfaction and loyalty on profits and growth: products versus services. Total Quality Management, 11(7), 917-927. http://dx.doi.org/10.1080/09544120050135461

Ennew, C., \& Schoefer, K. (2003). Service failure and service recovery in tourism: A review. Christel DeHaan Tourism and Travel Research Institute, Nottingham University Business School.

Fornell, C., \& Cha, J. (1994). Partial least squares. Advanced methods of marketing research, 407(3), 52-78.

Fornell, C., \& Larcker, D. F. (1981). Evaluating structural equation models with unobservable variables and measurement error. Journal of Marketing Research, 18(1), 39-50. http://dx.doi.org/10.2307/3151312

Fornell, C., \& Wernerfelt, B. (1987). Defensive marketing strategy by customer complaint management: a theoretical analysis. Journal of marketing research, 24(4), 337-346. http://dx.doi.org/10.2307/3151381

Grönroos, C. (1988). Service quality: The six criteria of good perceived service. Review of Business, 9(3), 10-13.

Hair Jr, J. F., Hult, G. T. M., Ringle, C., \& Sarstedt, M. (2016). A primer on partial least squares structural equation modeling (PLS-SEM). Sage Publications.

Hsiao, K. L., \& Chen, C. C. (2016). What drives in-app purchase intention for mobile games? An examination of perceived values and loyalty. Electronic Commerce Research and Applications, 16(January), 18-29. https://doi.org/10.1016/j.elerap.2016.01.001

Ikponmwen, E. (2011). The Effects of Service Recovery Satisfaction on Consumers' Behavioral Intentions: An Application in North Cyprus Five-Star Hotels (Doctoral dissertation, Eastern Mediterranean University (EMU)).

Inoue, Y., Funk, D. C., \& McDonald, H. (2017). Predicting behavioral loyalty through corporate social responsibility: The mediating role of involvement and commitment. Journal of Business Research, 75, 46-56. https://doi.org/10.1016/j.jbusres.2017.02.005

Jacoby, J., \& Chestnut, R.W. (1978). Brand loyalty measurement and management. New York: Wiley

Jaiswal, A. K., \& Niraj, R. (2011). Examining mediating role of attitudinal loyalty and nonlinear effects in satisfaction-behavioral intentions relationship. Journal of Services Marketing, 25(3), 165-175. http://dx.doi.org/10.1108/08876041111129155

Johnston, R., \& Mehra, S. (2002). Best-practice complaint management. The Academy of Management Executive, 16(4), 145-154. https://doi: 10.5465/AME.2002.8951342

Johnston, R., \& Michel, S. (2008). Three outcomes of service recovery: customer recovery, process recovery and employee recovery. International Journal of Operations \& Production Management, 28(1), 79-99. http://dx.doi.org/10.1108/01443570810841112

Jung, N. Y., \& Seock, Y. K. (2017). Effect of service recovery on customers' perceived justice, satisfaction, and word-of-mouth intentions on online shopping websites. Journal of Retailing and Consumer Services, 37, 23-30. https://doi.org/10.1016/j.jretconser.2017.01.012

Kakeeto-Aelen, T., Van Dalen, J., Van den Herik, J., \& Van de Walle, B. (2014). Building Customer Loyalty among SMEs in Uganda: The Role of Customer Satisfaction, Trust, and Commitment (No. 2014/06). Maastricht School of Management.

Kamran-Disfani, O., Mantrala, M. K., Izquierdo-Yusta, A., \& Martínez-Ruiz, M. P. (2017). The impact of retail store format on the satisfaction-loyalty link: An empirical investigation. Journal of Business Research, 77, 14-22. https://doi.org/10.1016/j.jbusres.2017.04.004

Kandulapati, S., \& Bellamkonda, R. S. (2014). Examining the structural relationships of service recovery, customer satisfaction and image in online retailing. Operations and Supply Chain Management, 7(2), 70-78.

Kau, A. K., \& Wan-Yiun Loh, E. (2006). The effects of service recovery on consumer satisfaction: A comparison between complainants and non-complainants. Journal of Services Marketing, 20(2), 101-111. 
http://dx.doi.org/10.1108/08876040610657039

Kaur, H., \& Soch, H. (2013). Mediating roles of commitment and corporate image in the formation of customer loyalty. Journal of Indian Business Research, 5(1), 33-51. http://dx.doi.org/10.1108/17554191311303376

Kim, G. S. (2007). The service recovery strategies, customer satisfaction, customer loyalty. Asian Journal on Quality, 8(1), 76-86. http://dx.doi.org/10.1108/15982688200700005

Kim, T., Jung-Eun Yoo, J., \& Lee, G. (2012). Post-recovery customer relationships and customer partnerships in a restaurant setting. International Journal of Contemporary Hospitality Management, 24(3), 381-401. http://dx.doi.org/10.1108/09596111211217879

Klarner, P., Sarstedt, M., Hoeck, M., \& Ringle, C. M. (2013). Disentangling the effects of team competences, team adaptability, and client communication on the performance of management consulting teams. Long Range Planning, 46(3), 258-286. http://dx.doi.org/10.1016/j.lrp.2013.03.001

Kock, N., \& Lynn, G.S. (2012). Lateral collinearity and misleading results in variance-based SEM: An illustration and recommendations. Journal of the Association for Information Systems, 13(7), 546-580.

Komunda, M., \& Osarenkhoe, A. (2012). Remedy or cure for service failure? Effects of service recovery on customer satisfaction and loyalty. Business Process Management Journal, 18(1), 82-103. http://dx.doi.org/10.1108/14637151211215028

Levesque, T. J., \& McDougall, G. H. (2000). Service problems and recovery strategies: an experiment. Canadian Journal of Administrative Sciences, 21, 20-37. http://dx.doi.org/10.1111/j.1936-4490.2000.tb00204.x

Lewis, B. R., \& McCann, P. (2004). Service failure and recovery: evidence from the hotel industry. International $\begin{array}{lllll}\text { Journal of Contemporary Hospitality } & \text { Management, }\end{array}$ http://dx.doi.org/10.1108/09596110410516516

Liao, H. (2007). Do it right this time: the role of employee service recovery performance in customer-perceived justice and customer loyalty after service failures. Journal of applied psychology, 92(2), 475-489. http://dx.doi.org/10.1037/0021-9010.92.2.475

Liat, C. B., Mansori, S., Chuan, G. C., \& Imrie, B. C. (2017). Hotel Service Recovery and Service Quality: Influences of Corporate Image and Generational Differences in the Relationship between Customer Satisfaction and Loyalty. Journal of Global Marketing, 1-10. http://dx.doi.org/10.1080/08911762.2016.1262932

Li-hua, Y. (2012). Customer satisfaction antecedents within service recovery context: Evidences from "Big 4" banks in China. Nankai Business Review International, 3(3), 284-301. http://dx.doi.org/10.1108/20408741211264585

Lii, Y. S., \& Lee, M. (2012). The joint effects of compensation frames and price levels on service recovery of online pricing error. Managing Service Quality: An International Journal, 22(1), 4-20. http://dx.doi.org/10.1108/09604521211198083

Lin, I. H. (2006). Perceptions of service failure, service recovery strategies, and behavioral intentions of hotel guests in Orlando, Florida.

Mason, D. D., Tideswell, C., \& Roberts, E. (2006). Guest perceptions of hotel loyalty. Journal of Hospitality \& Tourism Research, 30(2), 191-206.

McCollough, M. A., Berry, L. L., \& Yadav, M. S. (2000). An empirical investigation of customer satisfaction after service failure and recovery. Journal of service research, 3(2), 121-137.

Michel, S., Bowen, D., \& Johnston, R. (2009). Why service recovery fails: Tensions among customer, employee, and process perspectives. Journal of Service Management, 20(3), 253-273. http://dx.doi.org/10.1108/09564230910964381

Miller, J. L., Craighead, C. W., \& Karwan, K. R. (2000). Service recovery: A framework and empirical $\begin{array}{llll}\text { investigation. Journal of operations } & \text { Management, } & 18(4), & 387-400 .\end{array}$ http://dx.doi.org/10.1016/S0272-6963(00)00032-2

Morgan, R. M., \& Hunt, S. D. (1994). The commitment-trust theory of relationship marketing. The journal of marketing, 58, 20-38. http://dx.doi.org/10.2307/1252308

Mostafa, R. B., Lages, C. R., Shabbir, H. A., \& Thwaites, D. (2015). Corporate image: A service recovery perspective. Journal of Service Research, 18(4), 468-483. https://doi.org/10.1177/1094670515584146 
Mostafa, R., R. Lages, C., \& Sääksjärvi, M. (2014). The CURE scale: a multidimensional measure of service recovery strategy. Journal of Services Marketing, 28(4), 300-310. http://dx.doi.org/10.1108/JSM-09-2012-0166

Oliver, R. L. (1997). Varieties of value in the consumption satisfaction response. Advances in Consumer Research, 23(7), 247-254.

Oliver, R. L. (1999). Whence consumer loyalty? The Journal of Marketing, 63, 33-44. http://dx.doi.org/10.2307/1252099

Parasuraman, A., Berry, L. L., \& Zeithaml, V. A. (1991). Understanding customer expectations of service. MIT Sloan Management Review, 32(3), 39-48.

Park, J. J., \& Park, J. W. (2016). Investigating the effects of service recovery quality elements on passengers' behavioral intention. Journal of Air Transport Management, 53, 235-241. http://dx.doi.org/10.1016/j.jairtraman.2016.03.003

Petzer, D. J., Steyn, T. F. J., \& Mostert, P. G. (2009). Customer retention practices of small, medium and large hotels In South Africa: An exploratory study. African Journal of Marketing Management, 1(1), 032-042. http://dx.doi.org/10.5897/AJMM09.008

Rauyruen, P., \& Miller, K. E. (2007). Relationship quality as a predictor of B2B customer loyalty. Journal of business research, 60(1), 21-31. http://dx.doi.org/10.1016/j.jbusres.2005.11.006

Reichheld, F. F., \& Sasser, W. E. (1990). Zero defections: quality comes to services. Harvard Business Review, $68(5), 105-111$.

Roos, I. (1999). Switching processes in customer relationships. Journal of Service Research, 2(1), 68-85.

Sarstedt, M., Ringle, C. M., Smith, D., Reams, R., \& Hair, J. F. (2014). Partial least squares structural equation modeling (PLS-SEM): A useful tool for family business researchers. Journal of Family Business Strategy, 5(1), 105-115. http://dx.doi.org/10.1016/j.jfbs.2014.01.002

Saunders, M. N., Saunders, M., Lewis, P., \& Thornhill, A. (2011). Research methods for business students, 5/e. Pearson Education India.

Sciarelli, M., Nagm, A. A., Dakrory, M. I., Tani, M., \& Khashan, M. A. (2017). The Relationship between Service Recovery and Patronage Intentions: The Mediating Role of Relationship Quality. International Business Research, 10(8), 215-231. doi.org/10.5539/ibr.v10n8p215.

Singh, J., \& Sirdeshmukh, D. (2000). Agency and trust mechanisms in consumer satisfaction and loyalty judgments. Journal of the Academy of marketing Science, 28(1), 150-167.

Sirdeshmukh, D., Singh, J., \& Sabol, B. (2002). Consumer trust, value, and loyalty in relational exchanges. Journal of marketing, 66(1), 15-37. http://dx.doi.org/10.1509/jmkg.66.1.15.18449

Sousa, R., \& Voss, C. A. (2009). The effects of service failures and recovery on customer loyalty in e-services: An empirical investigation. International Journal of Operations \& Production Management, 29(8), 834-864. http://dx.doi.org/10.1108/01443570910977715

Stratemeyer, A. W., Geringer, S. D., \& Canton, A. (2014). An Exploratory Investigation of the Effects of Service Failures and Recovery Efforts on Customer Satisfaction. American Journal of Management, 14(3), 20-28.

Tax, S. S., Brown, S. W., \& Chandrashekaran, M. (1998). Customer evaluations of service complaint experiences: implications for relationship marketing. Journal of marketing, 62(2)60-76. http:// doi: 10.2307/1252161

Tenenhaus, M., Amato, S., \& Esposito Vinzi, V. (2004). A global goodness-of-fit index for PLS structural equation modeling. In Proceedings of the XLII SIS Scientific Meeting, 1, 739-742.

Wang, Y. S., Yeh, C. H., \& Liao, Y. W. (2013). What drives purchase intention in the context of online content services? The moderating role of ethical self-efficacy for online piracy. International Journal of Information Management, 33(1), 199-208. http://dx.doi.org/10.1016/j.ijinfomgt.2012.09.004

Wen, B., \& Geng-qing Chi, C. (2013). Examine the cognitive and affective antecedents to service recovery satisfaction: A field study of delayed airline passengers. International Journal of Contemporary Hospitality Management, 25(3), 306-327. http://dx.doi.org/10.1108/09596111311310991

Wirtz, J., \& Mattila, A. S. (2004). Consumer responses to compensation speed of recovery and apology after a service failure. International Journal of Service Industry Management, 15(2), 150-166. http://dx.doi.org/10.1108/09564230410532484 
Yang, C. C., \& Chao, C. C. (2017). How relationship marketing, switching costs, and service quality impact customer satisfaction and loyalty in Taiwan's air freight forwarding industry? Transportmetrica A: Transport Science, 13(8), 679-707. http://dx.doi.org/10.1080/23249935.2017.1321696

Yaya, L., Marimon, F., \& Casadesus, M. (2013). Can ISO 9001 improve service recovery? Industrial Management \& Data Systems, 113(8), 1206-1221. http://dx.doi.org/10.1108/IMDS-03-2013-0150

Yüksel, A., \& Rimmington, M. (1998). Customer-satisfaction measurement. The Cornell Hotel and Restaurant Administration Quarterly, 39(6), 60-70. https://doi.org/10.1016/S0010-8804(99)80007-X

Zeithaml, V. A., Berry, L. L., \& Parasuraman, A. (1996). The behavioral consequences of service quality. The Journal of Marketing, 60, 31-46. DOI: 10.2307/1251929

Zeithaml, V. A., Parasuraman, A., \& Berry, L. L. (1990). Delivering quality service: Balancing customer perceptions and expectations. Simon and Schuster.

Zemke, R., \& Bell, C. (1990). Service recovery: Doing it right the second time. Training, 27(6), 42-48.

\section{Copyrights}

Copyright for this article is retained by the author(s), with first publication rights granted to the journal.

This is an open-access article distributed under the terms and conditions of the Creative Commons Attribution license (http://creativecommons.org/licenses/by/4.0/). 